
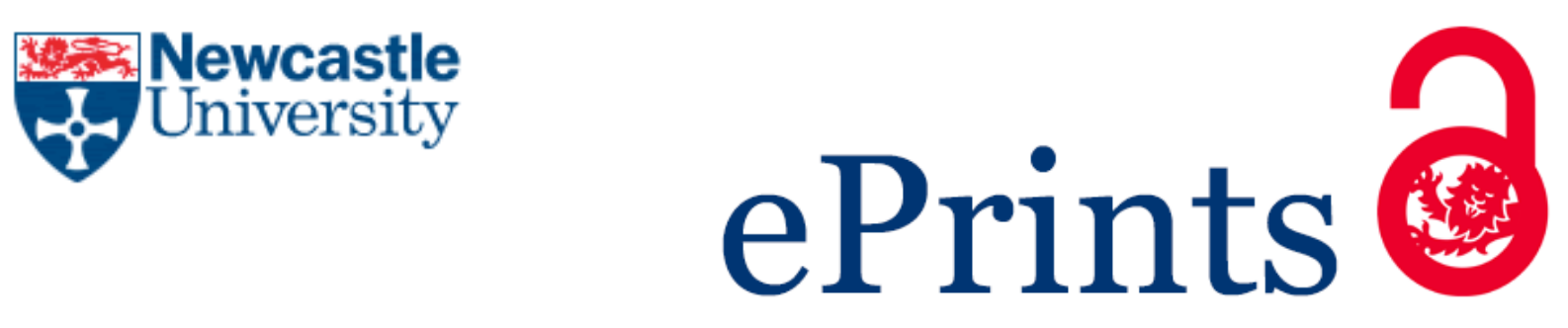

Rietig K.

$\underline{\text { Reinforcement of Multilevel Governance Dynamics: Creating Momentum for }}$ Increasing Ambitions in International Climate Negotiations. International Environmental Agreements: Politics, Law and Economics 2014, 14(4), 371-389.

Copyright:

The final publication is available at Springer via http://dx.doi.org/10.1007/s10784-014-9239-4

Date deposited:

$10 / 03 / 2016$

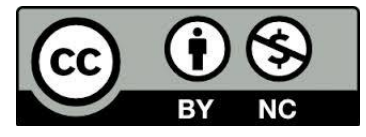

This work is licensed under a Creative Commons Attribution-NonCommercial 3.0 Unported License 


\title{
Reinforcement of multilevel governance dynamics: Creating momentum for increasing ambitions in international climate negotiations
}

\author{
Katharina Rietig \\ Department of Geography and Environment/ \\ Grantham Research Institute on Climate Change and the Environment \\ London School of Economics and Political Science \\ Houghton Street, WC2A 2AE London, k.m.rietig@1se.ac.uk
}

\begin{abstract}
Compared to the disappointment of the 2009 climate summit in Copenhagen the results of the recent Conferences of the Parties (COPs) can be regarded as positive progress. This was made possible due to lesson drawing and learning among states. Recent evidence from the UNFCCC negotiations suggests that countries began to reflect on the 'Copenhagen experience', are setting up domestic climate legislation in the form of low carbon development plans and are sharing their knowledge and experiences in the international climate negotiations. Country representatives engage in workshops and roundtables to showcase their mitigation plans and low carbon development initiatives, thereby raising ambitions and creating group pressure on other countries. This article examines how the diffusion of policies across countries is motivated and facilitated by knowledge transfer and learning within multilevel-reinforcing governance dynamics between the domestic level and international negotiations. It analyses how changes in the negotiation setting from confrontational formal negotiations to a more open forum and bottom-up pledge-and-review process, in combination with a positively framed win-win low carbon economic development narrative resulted in the diffusion of climate policies across developed and developing countries. Communicating these climate initiatives on the national level has shifted the debate. Countries emphasize less the win-lose perspective of economic costs and sacrifice. Thus they focus less on the question of 'who should reduce emissions', but identify co-benefits instead. The institutionalized knowledge sharing within the UNFCCC is also creating positive competitive dynamics among countries to increase their ambition and take on a leadership role. This shift in the negotiations carries potential for a more ambitious aggregate negotiation outcome and opens up a window of opportunity.
\end{abstract}

Keywords: International negotiations, climate change, policy diffusion, lesson-drawing, low carbon economic development, multilevel governance, UNFCCC. 


\section{Abbreviations}

AWG-ADP Ad Hoc Working Group on the Durban Platform for Enhanced Action AWG-KP Ad Hoc Working Group on Further Commitments for Annex I Parties under the Kyoto Protocol

AWG-LCA Ad Hoc Working Group on Long-term Cooperative Action under the Convention

COP Conference of Parties

EU European Union

IPCC Intergovernmental Panel on Climate Change

NAMAs Nationally Appropriate Mitigation Actions

NGO Nongovernmental Organization

UN United Nations

UNFCCC United Nations Framework Convention on Climate Change

\section{Introduction}

Efforts to limit climate change are at crossroads. On the international level, a patchwork approach of disintegrated regimes is emerging with more or less coordinated measures on the local, national and regional levels involving different actors. This is frequently referred to as 'fragmentation' (Biermann et al. 2009) of the global environmental governance architecture, an emerging 'bottom-up approach' (Rayner 2010), 'building-blocs' (Falkner et al. 2010), a 'climate regime complex' (Keohane and Victor 2011) or could be regarded as development in the tradition of two-level games (Putnam 1988). Key arenas are the UNFCCC, G8/ G20 and regional actors (Kim and Chung 2012).

The results of the recent COPs can be regarded as a positive progress when compared to the disappointment of the 2009 UNFCCC summit in Copenhagen. This progress was made possible due to learning from experience among states. Recent evidence from the UNFCCC negotiations suggests that countries began to reflect and draw lessons from the 'Copenhagen experience'. They are increasingly accepting that all countries need to contribute to climate mitigation. To achieve the corresponding climate treaty, countries are willing to accept modifications to the negotiation process by engaging in workshops and roundtables to showcase their mitigation action and low carbon 
development initiatives, thereby raising ambitions and sharing their experiences. This article examines how the diffusion of policies across countries is motivated and facilitated by knowledge transfer and learning within multilevel-reinforcing governance dynamics.

It analyses how changes in the negotiation setting from confrontational formal negotiations to a more open forum combined with a positively framed win-win low carbon economic development narrative results in the diffusion of climate policies across developed and developing countries. Communicating these climate initiatives on the international level shifted the debate. Countries emphasize less the win-lose perspective of economic costs and sacrifice, thus focusing less on the question of "who should reduce emissions'. Instead of this 'win-lose' mindset (Gupta 2012) they are increasingly asking about co-benefits on 'how can we all reduce emissions and create sustainable economic growth?' The institutionalized knowledge sharing within the UNFCCC is also creating positive competitive dynamics among countries to increase their ambition and take on a leadership role. This shift in the negotiations carries potential for a more ambitious aggregate negotiation outcome. The key hypothesis is that the diffusion of policies across countries is facilitated by international negotiations such as those within the UNFCCC, where countries are encouraged to present their national efforts and progress towards implementation. The UNFCCC has taken on the role of a forum to showcase countries' mitigation and adaptation activities, thus leading to positive reinforcement effects and group pressure.

To this end, this contribution analyses the reinforcing dynamics between the international level of climate negotiations within the UNFCCC and the national level of domestic climate legislation. It widens the analytical lens to include climate measures on the national level and emerging patterns of institutionalized knowledge transfer (Dolowitz and Marsh 1996; Zito and Schout 2009) within the UNFCCC. This dynamic has the potential to evolve into lesson-drawing (Rose 1991, 1993) or even policy-learning (Bennett and Howlett 1992; May 1992; Zito and Schout 2009), making policy success from the normative perspective more likely as it contributes to changing the prevailing understanding of climate change as a distributive problem (Gupta 2012) towards a win-win opportunity for sustainable development.

The first part reviews the most relevant academic literature on learning in policymaking, the top-down approach to addressing climate change based on regime theory and the bottom-up approach of the economic benefits from investment in low carbon economic development based on the emerging green growth literature. It introduces the 
theoretical framework on pathways in complex governance by Bernstein and Cashore (2012) as basis for the empirical analysis. Following the methodology section, the fourth part discusses countries' climate legislation and low carbon development plans. The fifth section draws attention to an emerging pattern of lesson-drawing in the UNFCCC negotiations, which increasingly serves as forum for countries to showcase their low carbon economic development strategies and engage in policy transfer (Dolowitz and Marsh 1996, 2012; Rose 1991, 1993). The final section concludes by discussing the resulting opportunity for reframing the international negotiations towards a 'win-win' narrative of understanding climate change mitigation as chance for sustainable, low carbon economic development and as an opportunity to focus on the co-benefits as countries already do in their national climate legislation.

\section{Links between climate governance, green growth and learning}

\subsection{The global climate governance literature}

Scholars concluded from the Copenhagen Accords that the approach of negotiating a comprehensive post-2012 climate agreement failed (e.g. Winkler and Beaumont 2010) mostly due to institutional dysfunctions of the UNFCCC monopoly (Keohane and Victor 2011, p. 15). Further reasons were the lack of inclusive leadership provided by some chairpersons when introducing compromise draft-texts and not allowing the parties sufficient time for discussions (Müller 2011) as well as institutional path-dependencies (for detailed analyses see Grubb 2011; Gupta 2012; Kjellén 2008; Rayner 2010; Rajamani 2012). This theoretical perspective prevails although the Cancun Agreements represent significant progress in the measure of UNFCCC's incremental steps thanks to the transparent and inclusive steering approach demonstrated by the Mexican COP-16 and South African COP-17 presidency and the shared desire of delegates to get any agreement at the Cancun COP-16 conference (Grubb 2011). Incremental, small steps are not the best option, but the only way the climate regime is currently evolving (Bodansky and Diringer 2010; Urpelainen 2013) due to constraints in its institutional architecture (Biermann et al. 2010; Hare et al. 2010) such as consensus-based decision-making. This ef- 
fectively grants each of the 194 countries a veto right (Keohane and Victor 2011). The UNFCCC can be regarded as a typical UN decision-making body. Its consensus-based decision-making structure means that all decisions meet the smallest common denominator and thus allow a high legitimacy (Buchanan and Keohane 1999), but it also means that the UNFCCC is locked-into a strong incrementalism regarding its (in-)ability to deliver the strong, legally binding agreement called for by the IPCC and the public. In short, its institutional architecture prohibited the UNFCCC in 2009 from delivering.

\subsection{Low carbon development literature}

The emerging green growth or low carbon (economic) development literature focuses on how countries can combine climate mitigation with economic development (Bowen and Fankhauser 2011a, 2011b; Jacobs 2012; Jänicke and Jacob 2009; Zenghelis 2011). It stands in the tradition of the Ecological Modernization literature focused on cobenefits between environmental protection and economic growth (e.g. Mol 1996; Lanoie et al. 2008; Porter and van der Linde 1995). This literature argues that economic growth and climate mitigation are not mutually exclusive, but there can be co-benefits for achieving both objectives if regulation corrects market failures and internalizes the costs of environmental externalities (Porter and van der Linde 1995). These include marketbased instruments and technology-pull policies by governments to stimulate private investment in low-carbon transport, energy efficiency and renewable energies (Zenghelis 2011). Proponents emphasize that investment in clean technologies and projects contributing to carbon mitigation support economic growth, the creation of jobs (Jänicke and Jacob 2009) and poverty reduction. This win-win approach of green growth on a macroeconomic scale is embraced by an increasing number of governments (Mathews 2012; Zhang 2011) on the national level, which remained independent from the continuing dominance of countries' 'win-lose' perspective of historic responsibilities within the UNFCCC between 2008 and 2011 as illustrated by Hallding et al. (2011) and Walsh et al. (2011). Academics who are also involved in policy making however are beginning to carefully map out how participation in the form of taking on commitments in the future could look like (Dubash 2012; Zhang 2011).

Both the international relations and the environmental economics literature refer to an emerging bottom-up approach in the climate regime, but rarely combine the pros- 
pect of using low carbon development strategies to overcome the deadlock in the international climate negotiations. This could be achieved via shifting the 'win-lose' narrative of costs and sacrifice linked to carbon mitigation efforts within UNFCCC (Gupta 2012) towards a positive 'win-win' approach of green growth, economic prosperity and job creation based on the investment in clean technologies and a quicker catch-up to the best available technologies at reasonably low costs in developing countries.

\subsection{Lesson drawing, policy transfer and learning from experience}

The international climate negotiations and domestic low carbon development literatures rarely link with each other. One exception is Bernstein and Cashore's (2012) four pathways of influence from the international to the domestic level. The first pathway is via international rules, either in the form of hard or soft law that result in compliance on the domestic level. These rules need not be issue specific, but can have co-benefits from another area (Bernstein and Cashore 2012, p. 590). The second pathway leads along international norms and discourse with a norm-guided 'logic of appropriateness' and a consequence-guided 'logic of consequences' (Bernstein and Cashore 2012, p. 591). Norms can also be disseminated via learning among actors resulting from interaction in transnational networks and at international conferences. The third pathway is via markets that influence consumer behaviour and thus domestic policy (Bernstein and Cashore 2012, p. 593). The fourth pathway is to directly access and influence the domestic policy making process via capacity building, i.e. the transfer of knowledge and provision of support to local actors sharing the same objectives (Bernstein and Cashore 2012, p. 593594). This is especially relevant with regards to policy learning when international efforts try to "build learning fora and training about how to produce improved environmental, social and economic performance 'on the ground"' (Bernstein and Cashore 2012, p. 594). Policy learning can occur in the decision-making process when stakeholder networks diffuse knowledge among government and non-governmental actors. It stimulates opportunities to benefit sustainability by uncovering "win-win opportunities that otherwise would fail to emerge owing to perceived conflicts" (Bernstein and Cashore 2012, p. 594). 
This contribution extends the pathways-framework from a 'one-way-street' into a cycle: the domestic initiatives that were stimulated by the international level facilitate convergence of positions in the international negotiations in the next round. Since states are already implementing appropriate policies on the domestic level and know how they can meet either existing or anticipated international commitments, they are more inclined to accept actual or further commitments in future negotiation rounds. Domestic experiences and knowledge on combining climate mitigation with economic development diffuse from the domestic level to the international negotiations, where other states pick up on those ideas. The international negotiations turn into a forum for knowledge transfer on domestic experiences. This enables countries to showcase their domestic actions as 'climate leaders'. Countries consequently learn from each other's successes and failures in implementing climate legislation. This builds up group pressure on 'laggards' to also develop and implement strategies as they are 'put in the spotlight'.

Learning in the sense of knowledge and experience transfer is a key determinant in the norms-based and capacity building pathways (Bernstein and Cashore 2012). The basis to learning is drawing lessons from experience with policy programmes in other countries or levels of governance (Bennett and Howlett 1992; Rose 1993). Lesson drawing is not an innovation itself but rather the utilisation of available experience (Rose 1991, 1993). It can occur by looking to other countries or levels of governance for solutions and evaluating whether these policies would also work in the specific domestic context. Lessons can be drawn from success stories and from failures regarding what mistakes to avoid (Rose 1991, p. 20-21). There are five possible modes of lesson drawing. Countries could simply copy the other policy, i.e. horizontally adopt an existing policy (Rose 1991, p. 21) or emulate it by adoption with modifications for the national framework conditions (Rose 1991, p. 21). They can also use hybridisation by combining two policies, synthesis by combining several elements of several policies, or inspiration, where other policies serve only as intellectual stimulus for a new policy (Rose 1991, p. 22). Lesson drawing is a process in which decision-makers voluntarily draw lessons from one or more countries and apply the positive or negative conclusions to their own policymaking. In contrast, policy transfer can also be forced upon decision-makers via supra-institutional actors, i.e. international rules (Bernstein and Cashore 2012). Consequently, lesson drawing can be seen as one aspect of policy transfer (Dolowitz and Marsh 1996, p. 344). 
The exchange of experiences with low carbon economic development plans on the international level can also potentially result in learning from experiences, for which to occur states need to reflect upon the policies presented to them and think about their usefulness for their domestic needs (May 1992; Zito and Schout 2009). Learning would occur if countries not only copied or adopted policies because they were pressured to do so as emphasised by the policy transfer literature (Dolowitz and Marsh 1996), but because they reflected on the activities of other countries and understand how they can move on a cleaner economic development path. Countries would thus also change their policy beliefs (Sabatier 1987, 1988) from focusing on economic sacrifices related to climate mitigation (win-lose) towards embracing co-benefits for sustainable economic development (win-win). Over time, we would also expect to see a change in secondary beliefs (Sabatier 1987, 1988) regarding policy details. The following sections analyze how and why the climate negotiations are showing indications of multilevel-reinforcement processes and interdependencies between international agreements and domestic climate legislation.

\section{Methodology}

The empirical analysis examines the relationship between climate legislation on the domestic level (independent variable) and the shift towards a 'win-win framing' in the international negotiations as dependent variable. The data was collected and analyzed between 2009 and 2013 using a qualitative sequential approach that allowed modifications to the original research design based on new additional data (King et al. 1994, p. 22) and a high number of observations within a single case-study design (King et al. 1994, p. 51).

The data includes 40 interviews with government representatives from developed and developing countries with at least two representatives from each negotiation bloc and is supplemented with information based on participant observation conducted by the author in 92 1.5-3 hour UNFCCC negotiation sessions such as plenary sessions, working groups, contact groups, informals, stakeholder roundtables, side events and workshops/ roundtables scheduled as part of the official UNFCCC meetings between 2009 and 2013. The researcher took notes of statements made by negotiators during these sessions 
and transcribed a number of negotiation sessions that were web-streamed via the UNFCCC website for textual analysis. This primary data was supplemented with document analysis of the Earth Negotiation Bulletin publications of the UNFCCC conferences between 2009 and 2012 (IISD 2007-2012). The data on national climate legislation is based on the GLOBE/ LSE study on climate legislation in 33 countries (Townshend et al. 2013). This primary and secondary data was coded using qualitative text analysis software and triangulated (Esterberg 2002) to answer the key research questions.

\section{Moving forward on the national level: domestic climate legislation}

Brazil, China, India, Mexico, South Africa and many more countries including Ethiopia and the Maldives are implementing low carbon economic development plans that were legislated in anticipation of a global agreement at the Copenhagen summit in 2009 or in response to the Copenhagen Accords and Cancun Agreements (UNFCCC 2010). Table 1 provides an overview of this recent climate legislation and the number of climate-related laws (Townshend et al. 2013). Developing countries set up fairly progressive climate legislation although they are not required to do so under the UNFCCC. The Cancun Agreements only encouraged developed countries, but the voluntary nature of NAMAs (UNFCCC 2012a) for developing countries triggered the development of climate legislation, which is predominantly framed as green growth or low carbon economic development (Upadhayaya 2010). Many of the climate laws address areas of cobenefits for climate mitigation/ adaptation and domestic priorities such as the protection of natural resources, carbon pricing, energy supply, adaptation, research and development and strengthening institutions and can thus be understood as climate policy integration. In the domestic debate, countries such as China (Zhang 2011), South Korea (Mathews 2012) and South Africa (Resnick et al. 2012) frame their climate legislation as green growth and low carbon economic development, while India for example focuses on co-benefits for poverty alleviation (PMCoCC 2008). 


\begin{tabular}{|c|c|c|c|c|c|c|c|c|c|c|}
\hline Country & $\begin{array}{l}\text { No. } \\
\text { laws }\end{array}$ & 2020 pledge & \begin{tabular}{|c|} 
Car- \\
bon \\
pric- \\
ing
\end{tabular} & \begin{tabular}{|c|} 
En- \\
ergy \\
de- \\
mand
\end{tabular} & $\begin{array}{c}\text { En- } \\
\text { ergy } \\
\text { supply }\end{array}$ & \begin{tabular}{|c|} 
Forests \\
and other \\
land use
\end{tabular} & $\begin{array}{l}\text { Trans- } \\
\text { port }\end{array}$ & \begin{tabular}{|c|} 
Ad- \\
apta- \\
tion
\end{tabular} & $\begin{array}{r}\mathrm{R} \\
\& \mathrm{D}\end{array}$ & $\begin{array}{c}\text { Institu- } \\
\text { tions/ } \\
\text { admin. ar- } \\
\text { rangement }\end{array}$ \\
\hline Argentina & 6 & No & & $\begin{array}{r}\text { Em- } \\
\text { phasis }\end{array}$ & $\mathrm{X}$ & & $\mathrm{X}$ & & $\mathrm{X}$ & $\mathrm{X}$ \\
\hline Australia & 9 & $\begin{array}{l}5-25 \% \text { from } 2000 \text {, con- } \\
\text { ditional }\end{array}$ & \begin{tabular}{|c|} 
Em- \\
phasis
\end{tabular} & $\mathrm{x}$ & $\mathrm{X}$ & $\mathrm{x}$ & $\mathrm{x}$ & $\mathrm{X}$ & & $\mathrm{X}$ \\
\hline $\begin{array}{l}\text { Bangla- } \\
\text { desh }\end{array}$ & 7 & No & & $\mathrm{x}$ & $\mathrm{X}$ & $\mathrm{X}$ & & $\begin{array}{c}\text { Em- } \\
\text { phasis }\end{array}$ & $\mathrm{X}$ & $\mathrm{X}$ \\
\hline Brazil & 13 & $\begin{array}{l}36-38 \% \text { from BAU, } \\
\text { voluntary }\end{array}$ & & $\mathrm{x}$ & $\mathrm{X}$ & $\begin{array}{l}\text { Empha- } \\
\text { sis }\end{array}$ & & $\mathrm{X}$ & $\mathrm{X}$ & $\mathrm{x}$ \\
\hline Canada & 4 & $17 \%$ from 2005 & & $\begin{array}{c}\text { Em- } \\
\text { phasis }\end{array}$ & $\mathrm{X}$ & & & & & \\
\hline Chile & 10 & $20 \%$ from $\mathrm{BAU}$ & & $\mathrm{X}$ & $\begin{array}{c}\text { Em- } \\
\text { phasis }\end{array}$ & $\mathrm{X}$ & & $\mathrm{x}$ & $\mathrm{X}$ & $\mathrm{X}$ \\
\hline China & 4 & $\begin{array}{c}\text { Reduce } \mathrm{CO}_{2} \text { emissions } \\
\text { per unit GDP by } 40-45 \% \text {, } \\
15 \% \text { of non-fossil fuel } \\
\text { energies in primary use, } \\
\text { increase forest cover }\end{array}$ & $\mathrm{X}$ & $\begin{array}{c}\text { Em- } \\
\text { phasis }\end{array}$ & $\mathrm{X}$ & $\mathrm{X}$ & $\mathrm{X}$ & $\mathrm{X}$ & $\mathrm{X}$ & $\mathrm{X}$ \\
\hline Colombia & 8 & $\begin{array}{l}>77 \% \text { share RE, } 0 \% \text { de- } \\
\text { forestation in Amazon } \\
\text { basin, } 20 \% \text { biofuels in } \\
\text { transport, depending on } \\
\text { external financial support }\end{array}$ & & $\mathrm{x}$ & $\mathrm{X}$ & $\begin{array}{l}\text { Empha- } \\
\text { sis }\end{array}$ & $\mathrm{X}$ & $\mathrm{x}$ & $\mathrm{X}$ & $\mathrm{X}$ \\
\hline $\begin{array}{l}\text { El Salva- } \\
\text { dor }\end{array}$ & 5 & No & & $\mathrm{x}$ & $\mathrm{x}$ & $\mathrm{x}$ & & $\begin{array}{c}\text { Em- } \\
\text { phasis }\end{array}$ & $\mathrm{X}$ & $\mathrm{X}$ \\
\hline Ethiopia & 8 & $\begin{array}{l}\text { Actions in RE, transport, } \\
\text { waste, agriculture, for- } \\
\text { estry, climate resilient } \\
\text { green economy initiative }\end{array}$ & & $\mathrm{x}$ & $\mathrm{X}$ & & $\mathrm{x}$ & $\begin{array}{c}\text { Em- } \\
\text { phasis }\end{array}$ & $\mathrm{X}$ & $\mathrm{X}$ \\
\hline $\begin{array}{l}\text { European } \\
\text { Union }\end{array}$ & 25 & $\begin{array}{l}\text { GHG reductions of } 20 \% \\
\text { from } 1990,30 \% \text { condi- } \\
\text { tional on climate treaty; } \\
20 \% \text { share of RE, } 20 \% \\
\text { increase in Energy Effi- } \\
\text { ciency }\end{array}$ & $\begin{array}{c}\text { Em- } \\
\text { phasis }\end{array}$ & $\mathrm{x}$ & $\mathrm{x}$ & $\mathrm{X}$ & $\mathrm{x}$ & $\mathrm{x}$ & $\mathrm{X}$ & $\mathrm{x}$ \\
\hline France & 14 & $\begin{array}{l}\text { EU GHG target, } 3 \% \text { an- } \\
\text { nual GHG reductions }\end{array}$ & $\mathrm{x}$ & $\begin{array}{c}\text { Em- } \\
\text { phasis }\end{array}$ & $\mathrm{X}$ & $\mathrm{x}$ & $\mathrm{X}$ & $\mathrm{X}$ & $\mathrm{X}$ & $\mathrm{x}$ \\
\hline Germany & 12 & $40 \%$ from 1990 levels & $\mathrm{x}$ & $\mathrm{x}$ & $\begin{array}{c}\text { Em- } \\
\text { phasis }\end{array}$ & & $\mathrm{X}$ & $\mathrm{X}$ & $\mathrm{X}$ & $\mathrm{x}$ \\
\hline India & 14 & $\begin{array}{l}\text { Voluntarily reduce emis- } \\
\text { sions intensity of GDP } \\
\text { (excl agriculture) by } 20 \text { - } \\
25 \% \text { from } 2005\end{array}$ & $\mathrm{X}$ & $\begin{array}{c}\text { Em- } \\
\text { phasis }\end{array}$ & $\mathrm{X}$ & $\mathrm{X}$ & $\mathrm{X}$ & $\mathrm{x}$ & $\mathrm{X}$ & $\mathrm{x}$ \\
\hline Indonesia & 18 & $26 \%$ from BAU & & $\mathrm{X}$ & $\mathrm{X}$ & $\begin{array}{l}\text { Empha- } \\
\text { sis }\end{array}$ & & & $\mathrm{X}$ & $\mathrm{X}$ \\
\hline Italy & 18 & $\begin{array}{c}\text { EU } 20 \% \text { GHG target/ } \\
\text { within } \mathrm{EU} \text { burden sharing } \\
\text { for RE/ EE }\end{array}$ & & $\begin{array}{c}\text { Em- } \\
\text { phasis }\end{array}$ & $\mathrm{X}$ & $\mathrm{X}$ & $\mathrm{X}$ & $\mathrm{X}$ & & $\mathrm{X}$ \\
\hline Jamaica & 3 & No & & $\mathrm{X}$ & $\mathrm{X}$ & $\mathrm{X}$ & & $\begin{array}{c}\text { Em- } \\
\text { phasis }\end{array}$ & $\mathrm{X}$ & $\mathrm{X}$ \\
\hline Japan & 9 & $\begin{array}{c}25 \% \text { from } 1990 \text { condi- } \\
\text { tional on post } 2012 \text { cli- } \\
\text { mate treaty involving ma- } \\
\text { jor emitters }\end{array}$ & $\mathrm{X}$ & $\begin{array}{c}\text { Em- } \\
\text { phasis }\end{array}$ & $\mathrm{X}$ & & $\mathrm{X}$ & & $\mathrm{X}$ & $\mathrm{X}$ \\
\hline Kenya & 5 & No & & $\mathrm{x}$ & $\mathrm{X}$ & $\mathrm{X}$ & & $\begin{array}{c}\text { Em- } \\
\text { phasis }\end{array}$ & & $\mathrm{X}$ \\
\hline Mexico & 8 & $\begin{array}{c}30 \% \text { GHG reduction } \\
\text { from BAU (conditional } \\
\text { upon financial and tech- } \\
\text { nical support) }\end{array}$ & $\mathrm{x}$ & $\mathrm{X}$ & $\begin{array}{c}\text { Em- } \\
\text { phasis }\end{array}$ & $\mathrm{x}$ & $\mathrm{X}$ & $\mathrm{X}$ & $\mathrm{X}$ & $\mathrm{X}$ \\
\hline
\end{tabular}




\begin{tabular}{|c|c|c|c|c|c|c|c|c|c|c|}
\hline \begin{tabular}{|l}
$\begin{array}{l}\text { Mozam- } \\
\text { bique }\end{array}$ \\
\end{tabular} & 4 & No & & & $\mathrm{X}$ & $\mathrm{X}$ & & \begin{tabular}{|c|}
$\begin{array}{c}\text { Em- } \\
\text { phasis }\end{array}$ \\
\end{tabular} & $\mathrm{X}$ & $\mathrm{X}$ \\
\hline Nepal & 3 & No & & & & & & \begin{tabular}{|c|} 
Em- \\
phasis
\end{tabular} & $\mathrm{X}$ & $\mathrm{X}$ \\
\hline Pakistan & 7 & No & & $\mathrm{X}$ & $\mathrm{X}$ & $\mathrm{X}$ & $\mathrm{X}$ & \begin{tabular}{|c|} 
Em- \\
phasis
\end{tabular} & $\mathrm{X}$ & $\mathrm{X}$ \\
\hline Peru & 6 & $\begin{array}{c}\text { Voluntary reduction of } \\
\text { net deforestation to zero, } \\
33 \% \text { of RE }\end{array}$ & & $\mathrm{X}$ & $\mathrm{X}$ & $\mathrm{X}$ & $\mathrm{X}$ & $\begin{array}{c}\text { Em- } \\
\text { phasis }\end{array}$ & $\mathrm{X}$ & $\mathrm{X}$ \\
\hline \begin{tabular}{|l} 
Philippi- \\
nes
\end{tabular} & 6 & No & & $\mathrm{X}$ & $\mathrm{X}$ & $\mathrm{X}$ & $\mathrm{X}$ & \begin{tabular}{|c|}
$\begin{array}{c}\text { Em- } \\
\text { phasis }\end{array}$ \\
\end{tabular} & $\mathrm{X}$ & $\mathrm{X}$ \\
\hline \begin{tabular}{|l|} 
Poland \\
\end{tabular} & 4 & $\begin{array}{l}\text { Within EU burden shar- } \\
\text { ing agreement }\end{array}$ & & $\mathrm{X}$ & $\begin{array}{l}\text { Em- } \\
\text { phasis }\end{array}$ & $\mathrm{X}$ & $\mathrm{X}$ & $\mathrm{X}$ & $\mathrm{X}$ & $\mathrm{X}$ \\
\hline Russia & 9 & $\begin{array}{c}15-25 \% \text { from } 1990 \text { de- } \\
\text { pending on appropriate } \\
\text { carbon sink accounting } \\
\text { and legally binding obli- } \\
\text { gations by all major emit- } \\
\text { ters }\end{array}$ & & \begin{tabular}{|c|} 
Em- \\
phasis
\end{tabular} & $\mathrm{X}$ & & & & & \\
\hline Rwanda & 3 & No & & $\mathrm{X}$ & $\mathrm{X}$ & $\mathrm{X}$ & $\mathrm{X}$ & \begin{tabular}{|c|}
$\begin{array}{c}\text { Em- } \\
\text { phasis }\end{array}$ \\
\end{tabular} & $\mathrm{X}$ & $\mathrm{X}$ \\
\hline $\begin{array}{l}\text { South Af- } \\
\text { rica }\end{array}$ & 4 & $\begin{array}{c}34 \% \text { from BAU } \\
\text { and } 42 \% \text { from BAU by } \\
2025\end{array}$ & $\mathrm{X}$ & $\mathrm{X}$ & $\begin{array}{c}\text { Em- } \\
\text { phasis }\end{array}$ & & & $\mathrm{X}$ & $\mathrm{X}$ & $\mathrm{X}$ \\
\hline \begin{tabular}{|c|} 
South \\
Korea \\
\end{tabular} & 16 & $30 \%$ from $\mathrm{BAU}$ & \begin{tabular}{|c|}
$\begin{array}{c}\text { Em- } \\
\text { phasis }\end{array}$ \\
\end{tabular} & $\mathrm{X}$ & $\mathrm{X}$ & $\mathrm{X}$ & $\mathrm{X}$ & $\mathrm{X}$ & $\mathrm{X}$ & $\mathrm{X}$ \\
\hline \begin{tabular}{|l|} 
United \\
Kingdom
\end{tabular} & 9 & $\begin{array}{c}\text { EU target; 34\% GHG } \\
\text { reduction; } 80 \% \text { by } 2050 \\
\text { from } 1990 \\
\end{array}$ & $\begin{array}{c}\text { Em- } \\
\text { phasis }\end{array}$ & $\mathrm{X}$ & $\mathrm{X}$ & $\mathrm{X}$ & $\mathrm{X}$ & $\mathrm{X}$ & $\mathrm{X}$ & $\mathrm{X}$ \\
\hline $\begin{array}{l}\text { United } \\
\text { States }\end{array}$ & 5 & $17 \%$ from 2005 & & $\mathrm{X}$ & $\begin{array}{l}\text { Em- } \\
\text { phasis }\end{array}$ & $\mathrm{X}$ & $\mathrm{X}$ & $\mathrm{X}$ & $\mathrm{X}$ & $\mathrm{X}$ \\
\hline Vietnam & 10 & No & & $\mathrm{X}$ & $\mathrm{X}$ & $\begin{array}{l}\text { Empha- } \\
\text { sis }\end{array}$ & $\mathrm{X}$ & $\mathrm{X}$ & $\mathrm{X}$ & $\mathrm{X}$ \\
\hline $\begin{array}{l}\text { Total } \\
\text { number of } \\
\text { laws/ topic }\end{array}$ & 286 & & $\begin{array}{c}11 / 3 \\
3\end{array}$ & $\begin{array}{c}31 / 3 \\
3\end{array}$ & $32 / 33$ & $25 / 33$ & $21 / 33$ & $\begin{array}{c}28 / 3 \\
3\end{array}$ & $\begin{array}{l}28 / \\
33\end{array}$ & $31 / 33$ \\
\hline
\end{tabular}

Table 1. National low carbon economic development plans/ climate legislation. Based on Townshend et al. (2013, p. 23-24). State of national legislation by October 2012; BAU = Business as Usual; $R E=$ Renewable Energies; EE = Energy Efficiency.

The number of climate-related laws increased since 1990 both in developed countries and in developing countries (Townshend et al 2013, p. 20). Three distinct peaks coincide with the implementation of the Kyoto protocol (1998-2006), anticipation of a legally binding climate treaty (2007-2009) and the emerging bottom-up approach of countries setting up legislation that falls into the category of voluntary initiatives following the 'failure' of COP-15 (2010 onwards). While Annex-1 countries to the Kyoto Protocol such as EU member states are predominantly implementing their international commitments, ${ }^{1}$ the mere fact that developing countries set up climate legislation given the absence of international rules indicates an emerging 'win-win' mindset on the na-

\footnotetext{
${ }^{1}$ Emphasized by multiple interviewees, e.g. European Commission (EC) 1, 2011; EC 2, 2011; EC 3 , 2011; EC 4, 2011; EC 5, 2012; EC6, 2012; EC7, 2012; Member of European Parliament (MEP) 1, 2012; MEP 2, 2012.
} 
tional level, pointing towards explanations from the three alternative pathways of international norms, markets and capacity building (Bernstein and Cashore 2012).

Several developments on the international level explain this diffusion of climate legislation. First, the shift in the debate to include developing countries into emission reduction commitments as major greenhouse gas emitters of the $21^{\text {st }}$ century had an impact on many developing countries to address climate change with legislation either in the run-up to the major 2009 climate change conference in Copenhagen or right afterwards. While national motivations differ, the timely proximity to the global peak attention on the climate change summit with over 100 heads of states participating indicates a certain 'deadline' pressure on countries to consider how they can adapt to the unavoidable consequences of climate change and develop with lower emission intensity (Interview findings 2010-2013). Secondly, the high political profile of the Copenhagen summit also "has been an eye opener to many of the attending politicians - particularly from the smaller developing countries - as to the importance accorded to climate change in other countries” (Müller 2011, p. 8). Furthermore, harvesting the 'low hanging fruits' of energy efficiency and co-benefits between renewable energy and energy security provided a further motivation, which is reflected in developing countries' climate change legislation as the Indian example illustrates (PMCoCC 2008).

This development can be explained with the pathways of influence of complex global governance on domestic policies introduced by Bernstein and Cashore (2012). For developed countries, who are predominantly listed in Annex-1 of the Kyoto Protocol, the domestic climate legislation can be understood as implementation of "binding obligations on states through international law" (Bernstein and Cashore 2012, p. 591), while the Cancun Agreements as non-binding international norm also created a "logic of appropriateness" (Bernstein and Cashore 2012, p. 592) for the developing countries. These agreed to set up and report NAMAs to the UNFCCC and consequently faced external pressures to also adapt domestic policies. The case of domestic climate legislation in developing countries pre-dating the Cancun Agreements (see Townshend et al. 2013, p. 20) however points towards another aspect: the anticipation of international norms.

This analysis of emerging domestic climate legislation in both developed and developing countries indicates governance dynamics on multiple levels, which in the case of the EU already resulted in reinforcing dynamics. However, the developing countries' negotiation positions have for a long time remained - and to a great extent still are - 
relatively static on the international level within the traditional win-lose mindset of sharing burdens, costs associated with mitigation efforts and reduced economic growth (IISD 2007-2013). Furthermore, finance and economic ministries that are frequently in charge of development issues often remain reluctant to embrace the low carbon development 'win-win' narrative and point towards the short-term economic benefits of the business-as-usual approach. This is also a reason why the Rio+20 Summit in 2012 remained far behind expectations in its outcomes - these negotiations were still caught in the dominant 1990s framing of economic sacrifice and short-term losses while countries were already doing more low carbon development on the domestic level than they were willing to politically commit to in the high-level intergovernmental negotiations. ${ }^{2}$

\section{Multilevel reinforcement via lesson-drawing in the UNFCCC}

Mutual exchange of experiences with national climate legislation is taking place at the 'margins' of the UNFCCC negotiations where government representatives engage with each other and nongovernmental actors in side-events and stakeholder dialogues. These meetings facilitate information exchange on domestic climate mitigation and adaptation activities and thus provide the opportunity for best-practice learning, lessondrawing and even policy transfer (Dolowitz and Marsh 1996; Rose 1991, 1993; Zito and Schout 2009). These learning forums focus on diffusing experiences on how improved environmental, economic and social performance can be produced on the domestic level. Agents of learning are members of the policy network, who are most influential when they manage to uncover "win-win opportunities that otherwise would fail to emerge owing to perceived conflicts" (Bernstein and Cashore 2012, p. 594). The following section thus widens the analysis beyond the current negotiation positions of key actors to another function of the UNFCCC as forum to exchange ideas and receive input from nongovernmental actors. A different picture of lesson-drawing and experience exchange emerges. This can result in a process that reinforces ambitions in the international negotiations based on the knowledge that countries can in fact deliver on their international commitments.

\footnotetext{
${ }^{2}$ IISD, 2007-2013; Interviews with developing country representatives, 2009-2011; participant observation 2009-2012 at UNFCCC conferences and Rio+20 in June 2012.
} 


\subsection{Low carbon development emerged at the periphery of the negotiations}

The 'win-win' narrative of low carbon development found its way to the 'periphery' of the UNFCCC Bonn negotiations in 2011 and has been strongly advocated by different groups of actors. Ban Ki Moon as UN Secretary General calls at the highest level for a 'green new deal' since COP-14 in Poland and welcomed India's national climate change strategy (UN 2008). Especially the 2009 G8(+5) summit in L'Aquila/Italy marked the introduction of low carbon narratives into the climate debate at the heads of states level (Interview with senior advisor in G8 delegation 2011). Before the anniversary of the Rio Earth Summit in 1992, the former UNFCCC Executive Secretary Ivo de Boer emphasised Ban Ki Moons' opportunity to mainstream green growth into sustainable development and bring the fight against climate change to the heart of the United Nations (DeBoer 2011). Ivo de Boer and the current UNFCCC Executive Secretary Christina Figueres emphasise the importance of green growth and low carbon development at almost every opportunity (IISD 2007-2013). They call on all countries to raise ambitions to close the gap towards the $2{ }^{\circ} \mathrm{C}$ target through international cooperation and to formalize these pledges into an international agreement (DeBoer 2010; Figueres 2011).

After overcoming their disappointment regarding the low ambition of the Copenhagen Accords, nongovernmental actors as representatives of civil society also played an important role in promoting green growth strategies at the 'margins' of the UNFCCC negotiations and communicating their position to government representatives. For example, stakeholders of civil society ranging from environmental NGOs to industry associations agreed at a workshop with government representatives from Mexico, South Africa and the EU that the discussions on mitigation too often focuses on costs, loss of jobs and GDP and that increased efforts need to be directed at "framing mitigation as a positive opportunity for creating jobs and 'green growth"' (Rambharos and Yamin 2011, p. 1) as the way forward on the longer term, while recognizing that NAMAs by developing countries are already substantial. The involvement of nongovernmental actors such as experts from environmental NGOs, academics and representatives of local and regional governments facilitates the process of information exchange via capacity building and additional experiences from the city and regional level. 
These positive reinforcing dynamics first emerged after the Cancun Agreements en route to the Durban negotiations in 2011, when the Mexican and South African presidencies organised several round tables at the Bonn Climate Change negotiations in June 2011 (IISD 2007-2013). The information exchange and knowledge transfer however remained outside the formal negotiations, which were still locked into the win-lose narrative dominant since the 1990s.

\subsection{Moving towards the core of the negotiations}

By May 2013 these reinforcing dynamics diffused into the core of the UNFCCC negotiations. The two traditional negotiation streams, the AWG-KP and AWG-LCA, had been closed and replaced by the Durban Platform on Enhanced Action towards a 2015 agreement (ADP). States had agreed to change the negotiation process towards an open workshop and roundtable structure including the participation of experts. These provided input in the form presentations to stimulate the negotiators' thinking. What would traditionally have been a 'side event' became the 'core event' as no other negotiations or parallel work streams were scheduled that would have diverted the negotiator's attention (UNFCCC 2013a). At the core of the week-long negotiations were workshops and roundtables on topics such as low carbon development, raising ambitions for mitigation, forestry, agriculture and technology transfer. The purpose was to encourage the negotiators to "offer reflections on [their] own experiences of implementing low emission strategies at various levels and to use this opportunity to discuss best practices and success stories at the national and international level" (Facilitator/ UNFCCC 2013a).

Not only developed countries participated and presented their achievements, but also developing countries that are under no obligation by the convention to set up any climate legislation. They also explained the rationale behind their climate legislation and shared their experience of setting up the process with the intention to help other countries better understand how they can design climate legislation: 
In Kenya, broadly speaking business has been the driver for mainstreaming actions into the development plan of the country. The impact of climate change was significant for us to present it to the planning ministry and for them to understand what would happen if we would not take that into consideration. (...) The other thing that helped us was the leadership of the ministry of environment. The minister helped us engaging with the ministers of finance and energy on that high level. So experts on these ministries were given instructions from their bosses on how to integrate climate change concerns into the process. Awareness created by NGOs since Copenhagen also helped. (...) This led to a legislation that made it through the parliament.

(Kenya/UNFCCC 2013a)

Kenya emphasized that in the context of the ADP "it is important that we increase ambition from the perspective of the developing and the developed countries, build confidence and trust as we move along" (Kenya/ UNFCCC 2013a). Unlike in previous negotiation rounds, where developing country negotiators refused to discuss measures that may lead to emission reduction in their countries while pointing towards the historical responsibility of developed countries (IISD 2007-2012), the question shifted from 'whether' developing countries should or should not reduce their emissions towards a goal-oriented information sharing of 'how' they can move towards a cleaner development pathway. One key example is the contribution of the Chinese chief negotiator when he explained the rationale behind climate mitigation and adaptation related measures of the $12^{\text {th }}$ five year plan:

\begin{abstract}
We regard low carbon development as innovation of the development pathway. Given that the two fundamental conventional pathways of the past 300 years, the first one of conventional technologies, has reached a level of 20 ton $\left[\mathrm{CO}_{2}\right]$ per capita and the second reached about 10 ton $\left[\mathrm{CO}_{2}\right]$ per capita. So now the challenge to developing countries like China is that we can't repeat the first two paths of development of the today industrialized countries. The world cannot afford such a high emission pathway. We are aware of the need to create a new innovative pathway for low carbon development. This is our vision to shape our strategy and to create technologies, policies and institutional arrangements to achieve that. Then we try to look at the goal and the solution. Yes, the goal should be ambitious, but we also need to find a feasible solution. (...) Having said that, I want to invite you to bless us and to support us, so let's work together for low carbon economic development.
\end{abstract}

(China/UNFCCC 2013a)

Negotiators also recognize their limitations to influence climate legislation and low carbon development on the domestic level. Key challenges are access to capital and technologies. They emphasize that "the people who should be in the room are finance and energy experts" (Nauru/ UNFCCC 2013a). Reflecting on the input, developed and developing countries asked to continue this novel approach to 
Build on this very constructive formal workshop and invite parties to share experiences of implementing low carbon and mitigation strategies. We should invite experts from civil society and the private sector to share their expertise and experiences in how we can overcome the challenges; this would be very useful for the June 2013 session, so that we can learn from other countries' challenges and obstacles and how we can overcome them. This can serve as the starting point for a more concrete and solution-oriented approach for our work towards a key step towards higher ambition for a more ambitious outcome.

(Nauru/UNFCCC 2013a)

Developed countries not only presented their achievements and financial support for technology transfer and mainstreaming climate objectives, but also welcomed the progress via this process and congratulated the 'frontrunners' among the developing countries with positive recognition:

I think it has been a very good debate and a clear sign. As Christiana [Figueres] said, a lot is happening. And sometimes you get the impression from this place that nothing is happening, but this is not the case. A lot is happening in developed and developing countries, not enough, but a lot. I think it would be very valuable to capture much of what has been said today and to invite more additions from colleagues so that we can extract the lessons for learning in a more systematic way. REDD is another example, I don't want to speak for Brazil, but they are a fantastic example and have done a great job in reducing deforestation over the past years, it's been one of the great global successes. They have done it in part through policing and it is cost effective to farm land in a more effective way, so it's both good for the climate, good for growth and for jobs, and we need to think about how we can generalize these sorts of lessons.

(EU/ UNFCCC, 2013a).

With the involvement of non-governmental actors such as the initiative of major cities $\mathrm{C} 40$, countries are reminded of the importance of implementation and the high support for climate legislation 'on the ground', i.e. by those who will need to deliver on the national targets:

C40 described the cooperation between the cities [, which] seems to be the ideal way, and if we as governments could cooperate in the same way it would seem as if the situation was humming, and I wonder if there are some things that the UNFCCC can do to help catalyze action from sub-national entities.

(United States/UNFCCC 2013a)

This approach was continued at the June 2013 UNFCCC negotiations in Bonn with another workshop and roundtable on low carbon development, which has been seen as "really important to get into the conversation and to think about how we can scale up, this shows the benefits of this kind of workshop and roundtable format. I think we are getting quite a lot of lessons and learning" (EU/UNFCCC 2013b). Even poor developing countries such as Bangladesh now demand that the agreement must be "applicable to all; rules-based; predictable, robust, clear, en- 
forceable and scientifically-sound; and take into account long-term perspectives, [common but differentiated responsibilities] and equity, and loss and damage" (IISD 2013, p. 13). Overall, more and more developing countries are realizing that they are vulnerable to climate change. Remarkably, this not only results in increased interest in adaptation, but also leads them to change their perspective regarding their own contribution to climate change. Like Kenya, Malaysia also arrived at the conclusion that domestic climate legislation in the form of low carbon plans is beneficial in the long term:

\begin{abstract}
Malaysia's communication on climate change published in 2010 has as its rationale that the continuing dependence on fossil fuels increased GHG, [what] made the country even more vulnerable to climate fluctuations and it further notes that economic competitiveness requires efficient energy production and energy consumption. The policy cites among its principles the importance of integrating climate change considerations into planning and implementation of national sustainable development plans on all levels of government that contribute to environmental conservation and use of natural resources and further highlights the importance of the participation of stakeholders and major groups.
\end{abstract}

(Malaysia/UNFCCC 2013b)

\title{
6 Discussion and conclusion on reinforcing dynamics
}

The dominant 'win-lose' frame of climate mitigation, which has hindered progress in the UNFCCC negotiations over the past 20 years, is beginning to be replaced by a 'win-win' framing that combines climate mitigation with low carbon development. The particular focus is on areas of 'low hanging fruits' such as energy efficiency and some forms of renewable energies. The UNFCCC is in a transitional phase as knowledge transfer on low carbon development plans occurs not only at the margins of the negotiations, but also at its core. This facilitates the diffusion of low carbon development plans across countries in the form of national climate legislation. It is frequently based on other countries' legislation and has been adapted to the domestic framework conditions. The lesson-drawing consequently occurs as emulation, but also as hybridization, synthesis and inspiration when countries only combine different aspects or use these as ideas for developing their own policies (Rose 1991). 
The inability of the UNFCCC to deliver the expected strong legally binding agreement at COP-15 in 2009 illustrates that the institutional architecture is a key determinant for the rate of progress. Due to the high number of veto points such as the requirement of consensus the UNFCCC is only capable of incremental steps, but these are insufficient to effectively address climate change within the closing window of opportunity (IPCC 2007, 2013). The Copenhagen Summit 2009 however also had a positive effect, which can facilitate progress towards a post-Kyoto agreement. The deadline pressure of COP-15 prompted many developed countries to set up climate legislation by 2009 (Townshend et al. 2013, p. 20). The general consensus to negotiate a universal post-Kyoto agreement, the realization of co-benefits from climate mitigation and the anticipation of international rules (Bernstein and Cashore 2012) encouraged developing countries to set up remarkable climate legislation before and after the Copenhagen summit. The presentations given by UNFCCC representatives in 2013 (UNFCCC 2013a, $2013 b$ ) indicate that there is much more climate legislation 'in the pipeline' than captured by the GLOBE/LSE study (Townshend et al. 2013), which examined only 33 countries but did not consider for example sub-national legislation, implementing programs/ strategies or small developing island states, many of which have pledged to become carbon neutral by 2020 or 2030 (UNFCCC 2013a). Their rationale is to increase other countries' ambitions by demonstrating 'if even we can become carbon neutral, so should the developed countries and emerging economies'.

These major developments towards a 'win-win' perspective and away from the 1990s 'win-lose' paradigm within the UNFCCC negotiations are no coincidence. The institutional dynamics within UNFCCC shifted towards a policy diffusion and knowledge transfer forum after the Durban negotiations with the Durban Platform on Enhanced Action, which was brokered by the EU at the end of the Durban negotiations (Rajamani 2012). The set-up of the negotiations has been altered within the AWG-ADP work streams by introducing workshops and roundtables as the only negotiation arena at the negotiations in May 2013, thus forcing countries to listen to each other and invited experts. This process began with informal stakeholder roundtables under the Mexican/ South African Presidencies in 2010/2011.

The UNFCCC motivated domestic climate legislation in compliance with international rules as 'first pathway' (Bernstein and Cashore 2012) for developed countries. Climate legislation in developing countries can be explained with the anticipation of international rules in the future and the emerging international norm that developing coun- 
tries should try to move towards a low carbon development path that combines economic growth with sustainable development and climate mitigation. Countries accepted this international norm in the AWG-ADP, which was adopted with consensus in 2011 (Rajamani 2012). The 'third pathway' of markets has played a minor role in this case. The 'fourth pathway' on capacity building (Bernstein and Cashore 2012) is a crucial linkage between the action on the national level motivated by the Copenhagen Accords, the Cancun Agreements (UNFCCC 2012b) and the emerging additional function of the UNFCCC as forum for knowledge transfer and experience exchange. It is thus evolving into a forum for capacity building. Consequently, the framework presented by Bernstein and Cashore (2012) can be regarded more as a cycle than a one-way path: international negotiations influence the domestic level, which in turn influences the international negotiations in their next cycle.

This capacity building and information sharing at the heart of the formal negotiations creates group pressure on countries to increase their ambition as a form of reinforcing competition: very few countries are indecisive to appearing as laggard who blocks action on climate change. The precedent that led to the adoption of the Cancun Agreements may have also contributed to this group pressure. When Bolivia objected and thus used its veto, it would have meant that the proposal for the Cancun Agreement had not been adopted by the UNFCCC. The Mexican presidency however overruled Bolivia's objection, what resulted in standing ovations and cheerful relieve among all other delegates present in the plenary hall (Interviews 2012). Consequently, the negotiation setting and the steering of the negotiation process are crucial determinants for the outcome. Modifications in the negotiation setting can have a positive influence on the negotiation process and ultimately facilitate an outcome. The UNFCCC negotiations in May 2013 set aside the contact groups where countries repeat their national positions without engaging with each other's positions. It replaced these with workshops and roundtables, encouraging countries to present their progress in reducing emissions and encouraging others to follow their example. This type of negotiation setting facilitates support via capacity building, knowledge transfer, increases exposure of countries and applies pressure to justify inaction and blame avoidance.

The diffusion literature has so far underestimated the importance of international negotiations as forum for knowledge transfer and the importance of positive reinforcement across governance levels via group pressure and competition. Countries are beginning to 'buy in' to the narrative of low carbon economic development emphasized by 
individuals with leadership roles such as the UNFCCC Executive Secretaries and the UN Secretary General. Countries' win-lose perspective and disagreements on who should take action is beginning to be replaced by the new development of a win-win framing that incorporates the element of positive competition and group pressure. This not only improves transparency and accountability in the climate negotiations, but also contributes to increasing countries' ambition and stimulates their thinking on setting up and implementing ambitious domestic climate legislation.

This bottom-up dynamic carries potential to be re-integrated into the top-down process of coordination within the UNFCCC, what will ultimately be necessary to coordinate mitigation action towards achieving a $2^{\circ} \mathrm{C}$ target based on the Cancun Agreements (UNFCCC 2010). The next 'window of opportunity' can open in 2015 (Jacobs 2012) with the results of the 2013-2015 review conducted by the subsidiary bodies of the UNFCCC on the gap between countries' aggregated individual mitigation efforts and the global $2^{\circ} \mathrm{C}$ target as well as the publication of the $5^{\text {th }}$ assessment report of the IPCC (IPCC 2013). If countries begin to see the benefits of domestic climate mitigation, their international negotiation position can potentially shift to facilitate such a post-Kyoto agreement, which in turn can provide momentum for further, more ambitious domestic low carbon development legislation and investment security in low emission technologies for the private sector.

Overall, these multilevel reinforcement dynamics between the international level that initiates responses on the national level, which in turn incrementally facilitates cooperation on the international level, can contribute to a 're-unification' of the fragmented climate regime under the United Nations Framework Convention on Climate Change. These findings carry wider implications for other areas of multilateral cooperation that merit further investigation. Key elements are the willingness of actors to reflect on the experience of 'negotiation failure' such as the Copenhagen summit in 2009 and to explore alternative modes of interaction such as non-negotiation settings. These allow exploring win-win opportunities and involving experts that provide 'neutral' input in the search for an approach that is acceptable to all negotiation parties involved. This requires actors to step back from politically deadlocked situations to assess the broader picture and mid- to long-term interests to go beyond a distributional zero-sum game by identifying mutual long-term objectives. 


\section{Acknowledgements:}

I am grateful to Michael Mason, Richard Perkins, Michele Betsill, Joyeeta Gupta, the participants of the climate governance workshop at the International Studies Association conference in San Francisco 2013, of the Grantham Research Institute Seminar in June 2013 and especially the two anonymous referees at International Environmental Agreements for their helpful feedback and comments on earlier versions of this article.

\section{Bibliography}

Abbott, K. (2011). The transnational regime complex for climate change. Environment and Planning C-Government and Policy, 30(4), 571-590.

Bennett, C., \& Howlett M. (1992). The Lessons of Learning: Reconciling Theories of Policy Learning and Policy Change. Policy Sciences, 25(3): 275-294.

Bernstein, S., \& Cashore, B. (2012). Complex global governance and domestic policies: four pathways of influence. International Affairs, 88(3), 585-604.

Biermann, F., Pattberg, P., van Asselt, H., \& Zelli, F. (2009). The fragmentation of Global Governance Architectures: A framework for analysis. Global Environmental Politics, 9(4), 14-40.

Biermann, F., Betsill, M., Gupta, J., Kanie, N., Lebel, L., Liverman, D., Schroeder, H., Siebenhüner, B., \& Zondervan, R. (2010). Earth System Governance: a research framework. International Environmental Agreements: Politics, Law and Economics, 10, $277-$ 298.

Bodansky, D. \& Diringer, E. (2010). The evolution of multilateral regimes: Implications for climate change. Washington D.C.: Pew Center for Global Climate Change, December 2010 .

Bowen, A., \& Fankhauser, S. (2011a). The green growth narrative: Paradigm shift or just spin? Global Environmental Change, 21(4), 1157-1159.

Bowen, A., \& Fankhauser, S. (2011b). Low-carbon development for the least developed Countries. World Economics, 12(1), 145-162.

Buchanan, A., \& Keohane, R. (1999). The legitimacy of global governance institutions. Rosenthal, J. (Ed). Ethics \& International Affairs. Washington D.C.: Georgetown University Press, 405-437.

De Boer (21/6/2010). Address by Yvo de Boer, Executive Secretary UNFCCC. Bonn, Deutsche Welle Global Media Forum 2010. Retrieved on 29/8/2011 from 
http://unfccc.int/files/press/news_room/statements/application/pdf/100621_speech_dw.p df.

De Boer (11/1/2011). Ban Ki-moon's green growth agenda can bring climate to the heart of the UN. GCC News Brief. Retrieved on 28/8/2011 from http://hendrawanm.wordpress.com/2011/01/30/ban-ki-moons-green-growth-agenda-canbring-climate-to-the-heart-of-the-un/.

Dolowitz, D., \& Marsh, D. (1996). Who Learns What from Whom: a Review of the Policy Transfer Literature. Political Studies, 44 (2), 343-357.

Dolowitz, D. \& Marsh, D. (2012). The future of policy transfer research. Political Studies Review, 10, 339-345.

Dubash, N. (2012) Handbook of Climate Change and India. Development, Politics and Government. London: Earthscan.

Esterberg, K. (2002). Qualitative Methods in Social Research. United States: McGraw Hill.

Falkner, R., Stephan H., \& Vogler, J. (2010). International Climate Policy after Copenhagen: Towards a 'Building Blocks' Approach. Global Policy, 1(3), 252-262.

Figueres (10/5/2011). Keynote speech by Christiana Figueres, Executive Secretary UNFCCC. New York, $17^{\text {th }}$ International Sustainable Development Research Conference.

Retrieved from

http://unfccc.int/files/press/news_room/statements/application/pdf/110510_speech_susta inable_development_conference.pdf.

Grubb, M. (2011). Cancun - the art of the possible. Climate Policy 11, 847-850.

Gupta, J. (2012). Negotiating challenges and climate change. Climate Policy, 12(5), 630-644.

Hallding, K., Olsson, A., Atteridge, A., Vihma, A., Carson, M., \& Roman, M. (2011). Together alone: BASIC countries and the climate change conundrum. Nordic Council of Ministers, Copenhagen. Retrieved on 20.9.2012 from

http://www.norden.org/en/publications/publikationer/2011-530.

Hare, W., Stockwell, C., Flachsland, C., \& Oberthür, S. (2010). The architecture of the global climate regime: a top-down perspective. Climate Policy, 10, 600-614.

Intergovernmental Panel on Climate Change (IPCC). (2007). Climate Change 2007:

Synthesis Report. Valencia: Intergovernmental Panel on Climate Change.

Intergovernmental Panel on Climate Change (IPCC). (2013). Climate Change 2013: The Physical Science Basis. Valencia: Intergovernmental Panel on Climate Change.

IISD Reporting Services (2007-2013). Earth Negotiations Bulletin of the United Nations Framework Convention on Climate Change, 12(322-579). Last retrieved on 15/6/2013 
from http://www.iisd.ca/vol12/. Winnipeg, International Institute for Sustainable Development.

IISD Reporting Services (2013). Summary of the Bonn Climate Change Conference: 314 June 2013. Earth Negotiations Bulletin of the United Nations Framework Convention on Climate Change, 12(580), 1-20.

Retrieved on 25/6/2013 from http://www.iisd.ca/download/pdf/enb12580e.pdf. Accessed on 25 June 2013.

Jacobs, M. (2012). Deadline 2015. Nature, 481, 137-138.

Jänicke, M., \& Jacob, K. (2009). A third industrial revolution? Solutions to the crisis of resource-intensive growth. Free University Berlin, Environmental Policy Research Centre, FFU-Report 2-2009.

Keohane, R., \& Victor, D. (2011). The Regime Complex for Climate Change. Perspectives on Politics, 9(1), 7-23.

Kim, J., \& Chung, S. (2012). The role of G20 in governing the climate change regime. International Environmental Agreements - Politics Law and Economics, 12(4), 361-374.

King, G., Keohane, R., \& Verba, S. (1994). Designing Social Inquiry. Scientific inference in Qualitative Research. Princeton: Princeton University Press.

Kjellén, B. (2008). A New Diplomacy for Sustainable Development. The Challenge of Global Change. London: Routledge.

Lanoie, P., Patry, M., \& Lajeunesse, R. (2008). Environmental regulation and productivity: Testing the Porter hypothesis. Journal of Productivity Analysis 30, 121-128.

Mathews, J. (2012). Green growth strategies - Korean initiatives. Futures, 44(8), 761769.

May, P. (1992). Policy learning and failure. Journal of Public Policy, 12(4), 331-354.

Mol, A. (1996). Ecological modernisation and institutional reflexivity: Environmental reform in the modern age. Environmental Politics, 5(2), 302-323.

Müller, B. (2011). UNFCCC - The future of the process. Remedial action on process ownership and political guidance. Climate Strategies, February 2011.

Porter, M., \& van der Linde, C. (1995). Toward a new conception of the environmentcompetitiveness relationship. Journal of Economic Perspectives, 9(4), 97-118.

Prime Minister's Council on Climate Change (PMCoCC). (2008). National Action Plan on Climate Change. New Delhi: Government of India.

Putnam, R.D. (1988). Diplomacy and domestic politics: the logic of two-level games. International Organization, 42: 427-460. 
Rajamani, L. (2012). The Durban Platform for Enhanced Action and the future of the climate regime. International \& Comparative Law Quarterly, 61(2), 501-518.

Rambharos, M., \& Yamin, F. (2011). The Cancun Agreements and the way forward. International Dialogue on Mitigation. Stakeholders Dialogue, Summary and Conclusions. 11/6/2011, Bonn, UNFCCC.

Rayner, S. (2010). How to eat an elephant: a bottom-up approach to climate policy. Climate Policy, 10, 615-621.

Resnick, D. (2012). The political economy of green growth: Cases from Southern Africa. Public Administration and Development, 32(3), 215-228.

Rose, R. (1991). What is lesson-drawing? Journal of Public Policy, 11(1), 3-30.

Rose, R. (1993). Lesson-drawing in public policy. Chatham NJ: Chatham House.

Sabatier, P. (1987). Knowledge, policy-oriented learning and policy change. Knowledge, 8: 649-692.

Sabatier, P. (1988). An advocacy coalition framework of policy change and the role of policy-oriented learning therein. Policy Sciences, 21: 129-168.

Townshend, T., Fankhauser, S., Aybar, R., Collins, M., Landesman, T., Nachmany, M., \& Pavese, C. (2013). GLOBE Climate Legislation Study. $3^{\text {rd }}$ edition, London: Globe International and Grantham Research Institute on Climate Change and the Environment of the London School of Economics and Political Science.

United Nations (UN) (11/12/2008). Secretary-General Ban Ki-Moon's opening statement to the high level segment of the United Nations Climate Change Conference. Poznan: UNFCCC. http://unfccc.int/files/meetings/

cop_14/statements/application/pdf/cop_14_statement_ban_ki-moon.pdf. Accessed 27 August 2011.

UNFCCC. (2010). Cancun Agreements. Decision FCCC/CP/2010/7/Add.1. New York: United Nations. http://unfccc.int/resource/docs/2010/cop16/eng/ 07a01.pdf\#page=2. Accessed 19 July 2012.

UNFCCC (2012a). Compilation of information on nationally appropriate mitigation actions to be implemented by Parties not included in Annex 1 to the Convention. Bonn, UNFCCC. http://unfccc.int/resource/docs/2011 /awglca14/eng/inf01.pdf. Accessed 15 April 2013.

UNFCCC (2012b). The Cancun Agreements. An assessment by the Executive Secretary of the United Nations Framework Convention on Climate Change.

http://cancun.unfccc.int/index.php\%20title. Accessed 27 July 2012.

UNFCCC. (2013a). Workshop on low emission development opportunities. ADP2. Bonn: UNFCCC. http://unfecc4.meta- 
fusion.com/kongresse/adp02/templ/play.php?id_kongresssession $=6359 \&$ theme $=$ unfccc. Accessed 18 May 2013.

UNFCCC (2013b). ADP 3 Workshop on pre-2020 ambition: Energy (Workstream 2). ADP 3. Bonn: UNFCCC. 7.6.2013. http://unfecc4.metafusion.com/kongresse/sb38/templ/play.php?id_kongresssession $=6464 \&$ theme $=$ unfccc. Accessed 28 June 2013.

Urpelainen, J. (2013). A model of dynamic climate governance: dream big, win small. International Environmental Agreements: Politics, Law, Economics, 13, 107-125.

Upadhyaya, P. (2010). Is emission trading a possible policy option for India? Climate Policy 10: 560-574.

Walsh, S., Tian, H., Whalley, J., \& Agarwal, M. (2011). China and India's participation in global climate negotiations. International Environmental Agreements: Politics, Law, Economics, 11: 261-273.

Winkler, H., \& Beaumont, J. (2010). Fair and effective multilateralism in the postCopenhagen climate negotiations. Climate Policy, 10, 638-654.

Zenghelis, D. (2011). A macroeconomic plan for a green recovery. Policy paper. Grantham Research Institute on Climate Change and the Environment, June 2011. http://www.cccep.ac.uk/Publications/Policy/docs/PP_macroeconomic-greenrecovery.pdf. Accessed 16 September 2011.

Zhang, Z. (2011). In what format and under what timeframe would China take on climate commitments? A roadmap to 2050. International Environmental Agreements: Politics, Law, Economics, 11: 245-259.

Zito, A., \& Schout, A. (2009). Learning theory reconsidered: EU integration theories and learning. Journal of European Public Policy, 16(8), 1103-1123. 